\author{
${ }^{1}$ A.K. Tuleshov, ${ }^{2}$ B.M. Merkibayeva ${ }^{(i D}$, B.I. Akhmetova \\ ${ }^{1}$ Dr. Sc., Professor, U.A.Dzholdasbekov Institute of Mechanics and Machine Science, Almaty, \\ Kazakhstan, E-mail: aman_58@mail.ru \\ ${ }^{2} \mathrm{PhD}$ student, E-mail: bakhyta23@mail.ru \\ ${ }^{3} \mathrm{PhD}$ student, E-mail: balzhanibragimovna@mail.ru \\ ${ }^{2,3}$ Al-Farabi Kazakh National University, Almaty, Kazakhstan
}

\title{
KINEMATIC ANALYSIS AND SYNTHESIS OF THE LEVER MECHANISM OF CRANK PRESS STAMPING
}

Expanding technical and technological capabilities of forging and stamping machines and equipment can be carried out by introducing new designs of actuators with wide functionality. These features are provided by the crank lever mechanisms of the press. This article presents a kinematic analysis and synthesis of a six-lever mechanism for stamping a crank press with a forging feed mechanism. We propose an analytical method for kinematic analysis of the mechanism, which allowed us to implement a numerical calculation program in the integrated Maple environment. Methods of kinematic synthesis of the six-lever crank press mechanism based on the standardsquare approximation, as well as the synthesis of the four-lever crank-slide forging feed mechanism have been developed. All the required constant geometric parameters of the stamping mechanism are determined; as a result, the mechanism implements the specified law of motion of the working slider with high accuracy. The comparative analysis was carried out in the ASIAN-2014 environment.

Key words: crank, press, linkage, the slider, the treatment of materials by pressure.

\author{
${ }^{1}$ А.К. Тулешов, ${ }^{2}$ Б.М. Меркибаева, ${ }^{3}$ Б.А. Ахметова

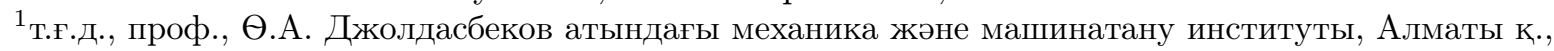 \\ Қазақстан, E-mail: aman_58@mail.ru \\ ${ }^{2} \mathrm{PhD}$ докторант, E-mail: bakhyta23@mail.ru \\ ${ }^{3} \mathrm{PhD}$ докторант, E-mail: balzhanibragimovna@mail.ru \\ 2,3Әл-Фараби атындағы Қазақ ұлттық университеті, Алматы қ., Қазақстан \\ Қосінді пресстің иінтіректі штампылау механизмін кинематикалық талдау және \\ синтездеу
}

Ұсталық-штампылау машиналары мен жабдықтарының техникалық және технологиялық мүмкіндіктерін кеңейтуді кең функционалды мүмкіндіктері бар атқарушы механизмдердің жаңа құрылымдарын енгізу есебінен жүргізуге болады. Мұндай мүмкіндіктерге престің қосиінді иінтіректі механизмдері ие. Бұл мақалада соғуды беру механизмі бар қосиінді престі штампылаудың алтыбуынды иінтіректі механизмінің кинематикалық талдауы және синтезі берілген. Механизмді кинематикалық талдау үшін аналитикалық әдіс ұсынылған, бұл интегралдық Maple ортасында сандық есептеу бағдарламасын жүзеге асыруға мүмкіндік берді. Орташа квадраттық жуықтау, сондай-ақ соғуды берудің төрт буынды қосиінді-жүгірткі механизмінің синтезі негізінде қосиінді престің алтыбуынды механизмінің кинематикалық синтезі әдістері әзірленді. Штампылау механизмінің барлық іздестірілетін тұрақты геометриялық параметрлері анықталды, нәтижесінде механизм жұмыс жүгірткісі қозғалысының берілген заңын жоғары дәлдікпен іске асырады. Салыстырмалы талдау ASIAN-2014 аймағында жүргізілді.

Түйін сөздер: қосиін, пресс, иінтіректі механизм, жүгірткі, материалдарды қысыммен өңдеу. 


\author{
${ }^{1}$ А.К. Тулешов, ${ }^{2}$ Б.М. Меркибаева, ${ }^{3}$ Б.А. Ахметова

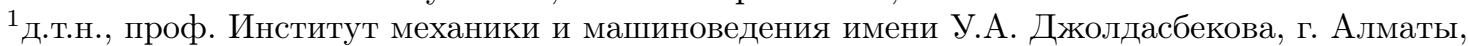 \\ Казахстан, E-mail: aman_58@mail.ru \\ ${ }^{2} \mathrm{PhD}$ докторант, E-mail: bakhyta23@mail.ru \\ ${ }^{3} \mathrm{PhD}$ докторант, E-mail: balzhanibragimovna@mail.ru \\ 2,3 Казахский национальный университет им. аль-Фараби, г. Алматы, Казахстан \\ Кинематический анализ и синтез рычажного механизма штамповки \\ кривошипного пресса
}

\begin{abstract}
Расширение технических и технологических возможностей кузнечно-штамповочных машин и оборудования можно проводить за счет внедрения новых конструкций исполнительных механизмов с широкими функциональными возможностями. Такими возможностями обладает кривошипные рычажные механизмы пресса. В данной статье представлен кинематический анализ и синтез шестизвенного рычажного механизма штамповки кривошипного пресса с механизмом подачи поковки. Предлагается аналитический метод кинематического анализа механизма, который позволил реализовать программу численного расчета в интегрированной среде Maple. Разработаны методы кинематического синтеза шестизвенного механизма кривошипного пресса на основе среднеквадратического приближения, также синтеза четырехзвенного кривошипно-ползунного механизма подачи поковки. Определены все искомые постоянные геометрические параметры механизма штамповки, в результате механизм с высокой точностью реализовывает заданный закон движения рабочего ползуна. Сравнительный анализ проведен в среде ASIAN-2014.
\end{abstract}

Ключевые слова: кривошип, пресс, рычажный механизм, ползун, обработка материалов давлением.

\title{
1 Introduction
}

To increase the competitiveness of forging and stamping equipment, it is necessary to increase its operational characteristics (accuracy, durability, efficiency, high manufacturability) while reducing overall development and production costs [1, 2]. This encourages the transition to modern design methods based on mathematical modeling of ongoing processes throughout the technological cycle and rational use of modern CAD tools. Expanding the technical and technological capabilities of forging machines and equipment can be carried out by introducing new designs of actuators with wide functionality. These features are provided by the crank lever mechanisms of the press. The development begins with solving the problems of kinematic synthesis and analysis of mechanisms.

\section{Literature review}

The development of new machine mechanism designs, including crank presses [1], begins with solving problems of analysis and synthesis based on mathematical modeling. When implementing the technological process in crank presses, it is necessary to provide a specified cyclogram of the movement of the working slider: fast ascent, dwell, slow descent. Research on crank presses considers two ways to achieve this goal, the first is to synthesize a mechanism with a single degree of freedom [2, 3, 4, 5], where these properties are embedded in the properties of the kinematic chain, the second is the solution of this problem due to the additional freedom of the kinematic chain, which are called the hybrid press system [6].

M. Erkan Kyutyuk's work [6] provides a review of the scientific literature on the analysis and synthesis of hybrid mechanisms of crank presses. In this paper, we consider a seven-way 
lever mechanism with two degrees of freedom (2 DOF), in which one degree operates on the basis of a DC power motor (for the implementation of the main technological process), the second - on the basis of a servomotor to provide a cyclogram of the technological process.

In many other studies, hybrid press systems are based on five-link and seven-link mechanisms with two degrees of freedom. The first study of this kind was performed by Dulger (originally Tokuz) and Jones in a hybrid configuration [7, 8, 9]. The constant-speed engine and servomotor were combined by a differential transmission, which further drives the crank mechanism [7].

Yuan and others explored the two combined machines having seven links, two DOF linkage [10]. Ouyang et al. proposed a five-link lever mechanism consisting of a five bar linkage, an AC CV motor and a frequency controller, an AC brushless servo motor and a servo amplifier with a gear transmission, a shift encoder, a flywheel and a belt [11]. Zhang proposed a hybrid five bar mechanism [12].

Connor et al. have presented a study on the synthesis of hybrid five bar path generating mechanisms using genetic algorithms [13]. Dulger et al. have presented a study on modeling and kinematic analysis of a hybrid actuator; a seven link mechanism with an adjustable crank [14]. Yu has offered a study with HM system using five bar mechanism [15]. Li and Zhang have applied a seven bar linkage configuration with kinematics analysis and optimum design of hybrid system [16]. Li and Tso have presented a seven bar mechanism [17]. Tso and Li have later used a seven bar mechanism to investigate the stamping capacity and energy distribution between the servomotor and the flywheel with different motion inputs [18]. Tso has again used a seven bar mechanism. A control system with iterative learning control and feedback control techniques was developed [19].

In all these mechanisms, the issue of providing the necessary cyclogram for moving the working slider is solved by controlling two or more engines and, accordingly, the problems of dynamic synthesis of drive control functions are solved.

The implementation of a technological cyclogram using a mechanism with a single degree of freedom requires a significant complication of the structure of the lever kinematic chain, the so-called Assur groups [20, 21]. In the works by A. Tuleshov [2, 3, 4, 5] a kinematic chain (structural group) of the fourth class is used for the synthesis of the crank press mechanism.

In [3], a vector method for kinematic analysis of crank two-rod presses has been developed on the basis of four-link groups [2]. As a follow-up to these studies, a vector model of the time diagram of the automaton was developed [2], which allows solving various dynamic problems by changing the parameters of the time cyclogram of its mechanisms, including the analysis of the mechanism using the Matlab / Simulink platforms [5]; based on this, it was possible to expand the motion scenarios for the slider with servo inputs. In [4], the authors used simulations to compare a conventional press with a power transmission using a crank mechanism and a press with an FEM yoke mechanism (Chval and Cechura 2014) [22].

\section{Material and methods}

\subsection{Structural analysis}

Figure 1 shows a kinematic diagram of the stamping mechanism under consideration with a feed-and-removal mechanism of the processed material. The structural formula of the mech- 
anism has the form [20].

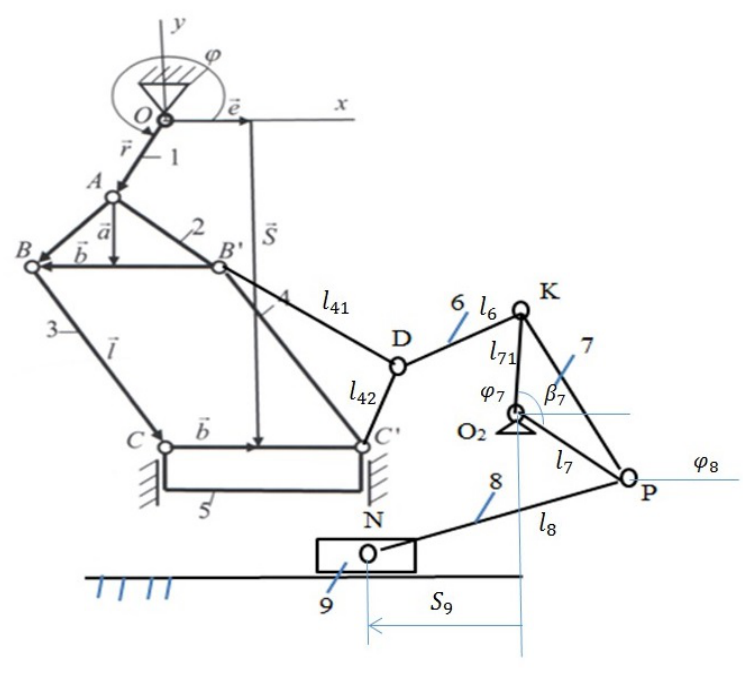

Figure 1: Kinematic schemes of the stamping mechanism

$$
I(1) \Rightarrow I V(2,3,4,5) \Rightarrow I I(6,7) \Rightarrow I I(8,9) .
$$

A special feature of the mechanism is that the modified contour $B B^{\prime} C^{\prime \prime} C$ is a parallelogram and the $A B B^{\prime}$ triangle is equilateral. This imposes certain conditions on the movement of individual joints: joint 2 makes a forward movement on the plane and joints 3 and 4 occupy the same angular positions.

The following symbols for the coordinates and dimensions of joints were introduced: $r$ - length of crank $1 ; a$ - height of $A B B^{\prime}$ triangle; $l$ - length of parallel connecting rods $B C=B^{\prime} C^{\prime} ; \varphi$ - angular coordinate of crank $1 ; \psi$ - angular coordinate of two connecting rods 3 and $4 ; S$ - linear coordinate of slide $5 ; e$ - eccentricity of slide 5 , i.e. the deviation of the trajectory of the center of gravity of the slider from $O y$ axis; $b$ - distance between ball joint $C$ and the center of the slide 5 along $O x$ axis; $l_{i, j}$ - the length of the leash triangular joints, where $i=4.7$ takes the number value of the joint $j=1,2$ - number of sides on a $i$ triangle; $l_{i}$ - the length of the $i$-joint; $\varphi_{i}$ - angular coordinate of the $i$-joint; $S_{9}$ - movement of slide 9 parallel to the axis $O_{2} x$.

\subsection{Kinematic analysis}

The kinematics equations of the Stephenson mechanism $I(1) \Rightarrow I V(2,3,4,5)$ in the crank press structure have the form [2]

$$
\left\{\begin{array}{l}
r \cos \varphi+l \cos \psi=e \\
r \sin \varphi-a+l \sin \psi=-S
\end{array}\right.
$$


Solutions of equations (1) with respect to $S=S(\varphi), \psi=\psi(\varphi)$ are obtained explicitly

$$
\left\{\begin{array}{l}
S=a-r \sin \varphi \pm \sqrt{l^{2}-(e-r \cos \varphi)^{2}} \\
\psi= \pm \arccos \left[\frac{1}{l}(e-r \cos \varphi)\right]
\end{array}\right.
$$

The signs \pm correspond to different assemblies of the mechanism.

The first and second derivative (analogs of speed and acceleration) are written as

$$
\begin{aligned}
& \left\{\begin{array}{l}
S^{\prime}=-r \cos \varphi-l \cos \psi \cdot \psi^{\prime} \\
\psi^{\prime} \sin \psi=-\frac{r}{l} \sin \varphi
\end{array}\right. \\
& \left\{\begin{array}{l}
S^{\prime \prime}=r \sin \varphi+l \sin \psi \cdot \psi^{\prime 2}-l \cos \psi \cdot \psi^{\prime \prime} \\
\psi^{\prime \prime} \sin \psi+\cos \psi \cdot \psi^{\prime 2}=-\frac{r}{l} \cos \varphi
\end{array}\right.
\end{aligned}
$$

Solutions of equations (3) and (4) with respect to the first and second derivative are written as

$$
\begin{array}{ll}
1^{\circ} \quad T_{\psi}^{\prime}(\varphi)=\psi^{\prime}=-\frac{r}{l} \frac{\sin (\varphi)}{\sin (\psi)}, \quad \sin (\psi) \neq 0, \quad \psi \neq 0, \quad k \pi, \quad k=1,2,3, \ldots \\
2^{\circ} \quad T_{S}^{\prime}(\varphi)=S^{\prime}=-r \cos \varphi-l \cdot T_{\psi}^{\prime}(\varphi) \cos \psi, \\
3^{\circ} \quad T_{\psi}^{\prime \prime}(\varphi)=\psi^{\prime \prime}=-\frac{1}{\sin \psi}\left[\frac{r}{l} \cos \varphi-\left(T_{\psi}^{\prime}\right)^{2} \cos \psi\right], \quad \sin \psi \neq 0, \quad \psi \neq 0, \quad k \pi, \quad k=1,2,3, \ldots \\
4^{\circ} \quad T_{S}^{\prime \prime}(\varphi)=S^{\prime \prime}=r \sin \varphi+l \cdot\left(T_{\psi}^{\prime}\right)^{2} \sin \psi-l \cdot T_{\psi}^{\prime \prime} \cos \psi .
\end{array}
$$

In real crank presses, the eccentricity $e=0$, the above formulas are slightly simplified and the algorithm for kinematic analysis of the mechanism is recorded

$$
\begin{aligned}
& 1^{\circ}\left\{\begin{array}{l}
S=a-r \sin \varphi \pm \sqrt{l^{2}-r^{2} \cos ^{2} \varphi} \\
\psi= \pm \arccos \left[\frac{r}{l} \cos \varphi\right]
\end{array}\right. \\
& 2^{\circ}\left\{\begin{array}{l}
S^{\prime}=-r \cos \varphi \pm \frac{r^{2} \sin \varphi}{2 \sqrt{l^{2}-r^{2} \cos ^{2} \varphi}} \\
\psi^{\prime}=\mp \frac{r \sin \varphi}{\sqrt{l^{2}-r^{2} \cos ^{2} \varphi}}
\end{array}\right. \\
& 3^{\circ}\left\{\begin{array}{l}
S^{\prime \prime}=r \sin \varphi \pm r^{2}\left(\frac{\cos \varphi}{\sqrt{l^{2}-r^{2} \cos ^{2} \varphi}}-\frac{r^{2} \sin ^{2} \varphi \cos \varphi}{2\left(l^{2}-r^{2} \cos ^{2} \varphi\right)^{3 / 2}}\right) \\
\psi^{\prime \prime}= \pm r\left(\frac{\cos \varphi}{\sqrt{l^{2}-r^{2} \cos ^{2} \varphi}}-\frac{r^{2} \sin ^{2} \varphi \cos \varphi}{2\left(l^{2}-r^{2} \cos ^{2} \varphi\right)^{3 / 2}}\right)
\end{array}\right.
\end{aligned}
$$

Next, we make the kinematics equations for the following mechanism structures $I I(6,7) \Rightarrow$ $I I(8,9)$. To do this, write down the coordinates of the joints $B^{\prime}$ and $C^{\prime}$ :

$$
x_{B^{\prime}}=r \cos \varphi+b, \quad y_{B^{\prime}}=r \sin \varphi-a, \quad x_{C^{\prime}}=e+b, \quad y_{C^{\prime}}=S .
$$


Let us write the equations of the geometric connection of a $B^{\prime} D C^{\prime}$ triangle:

$$
\begin{aligned}
& \left(x_{B^{\prime}}-x_{D}\right)^{2}+\left(y_{B^{\prime}}-y_{D}\right)^{2}=l_{41}^{2}, \\
& \left(x_{D}-x_{C^{\prime}}\right)^{2}+\left(y_{D}-y_{C^{\prime}}\right)^{2}=l_{42}^{2},
\end{aligned}
$$

The solution of this system of equations with respect to two unknowns $x_{D}$ and $y_{D}$ can be represented as [1]

$$
\left(x_{D}\right)_{1,2}=\frac{B \pm \sqrt{B^{2}-A C}}{A}, \quad\left(y_{D}\right)_{1,2}=c\left(x_{D}\right)_{1,2}+d,
$$

where $A=1+c^{2}, B=c\left(y_{B^{\prime}}-d\right), C=x_{B^{\prime}}^{2}+\left(y_{B^{\prime}}-d\right)^{2}-l_{41}^{2}$,

$$
c=\frac{x_{C^{\prime}}-x_{B^{\prime}}}{y_{C^{\prime}}-y_{B^{\prime}}}, \quad d=\frac{l_{41}^{2}-l_{42}^{2}+x_{C^{\prime}}^{2}-x_{B^{\prime}}^{2}+y_{C^{\prime}}^{2}-y_{B^{\prime}}^{2}}{2\left(y_{C^{\prime}}-y_{B^{\prime}}\right)}, \quad y_{C^{\prime}} \neq y_{B^{\prime}} .
$$

Let us write similar geometric connection equations for the group $I I(6,7)$

$$
\begin{gathered}
\left(x_{D}-x_{K}\right)^{2}+\left(y_{D}-y_{K}\right)^{2}=l_{6}^{2}, \\
\left(x_{K}-x_{O_{2}}\right)^{2}+\left(y_{K}-y_{O_{2}}\right)^{2}=l_{71}^{2},
\end{gathered}
$$

The $x_{O_{2}}, y_{O_{2}}$ coordinates are calculated, then the solution of this system of equations with respect to two unknowns $x_{K}$ and $y_{K}$ can be represented as

$$
\left(x_{K}\right)_{1,2}=\frac{B \pm \sqrt{B^{2}-A C}}{A}, \quad\left(y_{K}\right)_{1,2}=c\left(x_{K}\right)_{1,2}+d,
$$

where $A=1+c^{2}, B=c\left(y_{D}-d\right), C=x_{D}^{2}+\left(y_{D}-d\right)^{2}-l_{6}^{2}$,

$$
c=\frac{x_{O_{2}}-x_{D}}{y_{O_{2}}-y_{D}}, \quad d=\frac{l_{6}^{2}-l_{71}^{2}+x_{O_{2}}^{2}-x_{D}^{2}+y_{O_{2}}^{2}-y_{D}^{2}}{2\left(y_{O_{2}}-y_{D}\right)}, \quad y_{O_{2}} \neq y_{D} .
$$

Let us determine $\varphi_{7}$ angle of the angular position of joint $7\left(\mathrm{O}_{2} P\right)$ using the formula

$$
\varphi_{7}=2 \pi-\beta_{7}+\tan ^{-1} \frac{y_{K}-y_{O_{2}}}{x_{K}-x_{O_{2}}} .
$$

Now let us write the kinematics equations for the rocker-slider mechanism $I(7) \Rightarrow I I(8,9)$ in the following form

$$
x_{N}=x_{O_{2}}+l_{7} \cos \varphi_{7}+l_{8} \cos \varphi_{8}, \quad y_{N}=y_{O_{2}}+l_{7} \sin \varphi_{7}+l_{8} \sin \varphi_{8} .
$$

Given that we have the kinematics equation $x_{N}-x_{O_{2}}=S_{9}$ and $y_{N}-y_{O_{2}}=h_{9}=$ const

$$
S_{9}=l_{7} \cos \varphi_{7}+l_{8} \cos \varphi_{8}, \quad l_{7} \sin \varphi_{7}+l_{8} \sin \varphi_{8}=h_{9} .
$$

Whence

$$
\varphi_{8}= \pm \sin ^{-1} \frac{h_{9}-l_{7} \sin \varphi_{7}}{l_{7}}+k \pi, \quad k=0,1,2,3, \ldots, \quad S_{9}=l_{7} \cos \varphi_{7}+l_{8} \cos \varphi_{8},
$$




\subsection{Choosing the law of motion}

It is required to carry out the synthesis of the crank press reproducing the specified law of motion, $S_{M}=S_{M}(\varphi)$ on the site $0 \leq \varphi \leq 2 \pi$.

Let us assume that it is necessary to implement an equidistant law of motion of the slider to the crank press. Then the analog of the slider accelerations has the form [1, 21]

$$
T_{S M}^{\prime \prime}(\varphi)=\left\{\begin{array}{l}
a_{0} \text { at } 0 \leq \varphi \leq 0,5 \varphi_{y} \\
-a_{0} \text { at } 0,5 \varphi_{y}<\varphi \leq \varphi_{y}
\end{array}\right.
$$

where $a_{0}=$ const is the amplitude of the acceleration analog.

Using the unit function, equation (15) has the form

$$
T_{S M}^{\prime \prime}(\varphi)=a_{0}-2 a_{0} \delta\left(\varphi-0,5 \varphi_{y}\right),
$$

where $\delta\left(\varphi-\varphi_{0}\right)=\left\{\begin{array}{ll}0 & \text { at } \varphi \leq \varphi_{0} \\ 1 & \text { at } \varphi>\varphi_{0}\end{array}\right.$ is the Dirac unit function.

By double integrating $T_{S M}^{\prime \prime}(\varphi)$ function we get the position functions (18) and the analog of the slider speed (17)

$$
\begin{aligned}
& T_{S M}^{\prime}(\varphi)=a_{0} \varphi-2 a_{0}\left(\varphi-0,5 \varphi_{y}\right) \delta\left(\varphi-0,5 \varphi_{y}\right)+C \\
& S_{M}=T_{S M}(\varphi)=0,5 a_{0} \varphi^{2}-a_{0}\left(\varphi-0,5 \varphi_{y}\right)^{2} \delta\left(\varphi-0,5 \varphi_{y}\right)+C \varphi+D,
\end{aligned}
$$

where $C, D$ - are integration constants defined from initial conditions, if $\varphi=\varphi_{0}=0$, $T_{S M}\left(\varphi_{0}\right)=0, T_{S M}^{\prime}\left(\varphi_{0}\right)=0$, then $C=0, D=0$.

From the boundary condition $T_{S M}\left(\varphi_{0}\right)=T_{\max }$, we determine the amplitude of the acceleration analog

$$
a_{0}=4 T_{\max } / \varphi_{y}^{2}
$$

\subsection{Kinematic synthesis of the stamping mechanism}

From the kinematic scheme of the six-lever crank press stamping mechanism, we have [5]

$$
S(\varphi)=T_{S}(\varphi)=a-r \sin \varphi \pm \sqrt{l^{2}-(e-r \cos \varphi)^{2}} .
$$

The task of kinematic synthesis is to determine the constant parameters of the six-lever mechanism $a, l, r,, \varphi_{0}$ from the minimum functional conditions [5]

$$
\left\|S(\varphi)-S_{M}(\varphi)\right\| \underset{l, a, r, e, \varphi_{0}}{\Longrightarrow} \min
$$

The solution of the synthesis problem based on functional (21) has difficulties related to the nonlinearity of functions (2) (or (20)) and (18). Therefore, we apply another method related to the implicit representation of the kinematics equation of the mechanism and its transformations. To do this, we exclude the angle $\psi$ from equation (1), then we get

$$
l^{2}=a^{2}+S^{2}+e^{2}+r^{2}-2 a S-2 a r \cdot \sin \varphi+2 S r \cdot \sin \varphi-2 r e \cdot \cos \varphi
$$


Replace in equation (22) $S$ with $S_{i}+S_{0}$ and $\varphi$ to $\varphi_{i}+\varphi_{0}$ to account for the reference point $S_{i}$ and $\varphi_{i},=1,2, \ldots, N$

$$
\begin{aligned}
& l^{2}=a^{2}+\left(S_{i}+S_{0}\right)^{2}+e^{2}+r^{2}-2 a\left(S_{i}+S_{0}\right)-2 a r \cdot \sin \left(\varphi_{i}+\varphi_{0}\right)+ \\
& +2\left(S_{i}+S_{0}\right) r \cdot \sin \left(\varphi_{i}+\varphi_{0}\right)-2 r e \cdot \cos \left(\varphi_{i}+\varphi_{0}\right)
\end{aligned}
$$

We define the deviation function, which expresses the degree of proximity of the movement of the working joint and reproduced by the mechanism (21), in the form

$$
\Delta_{i}=\Delta_{i}\left(\varphi_{i}, S_{i}\right), \quad i=1,2, \ldots, N,
$$

where

$$
\begin{aligned}
& \Delta_{i}\left(\varphi_{i}, S_{i}\right)=a^{2}+\left(S_{i}+S_{0}\right)^{2}+e^{2}+r^{2}-l^{2}-2 a\left(S_{i}+S_{0}\right)-2 a r \cdot \sin \left(\varphi_{i}+\varphi_{0}\right)+ \\
& +2\left(S_{i}+S_{0}\right) r \cdot \sin \left(\varphi_{i}+\varphi_{0}\right)-2 r e \cdot \cos \left(\varphi_{i}+\varphi_{0}\right)
\end{aligned}
$$

After transformations of the last expression, we get, assuming $S_{0}=0$

$$
\Delta_{i}=P_{0} f_{0 i}+P_{1} f_{1 i}+P_{2} f_{2 i}+P_{3} f_{3 i}+P_{4} f_{4 i}+P_{5} f_{5 i}-F_{i}
$$

The following symbols are introduced here:

$$
\begin{aligned}
& f_{0 i}=1 ; \quad f_{1 i}=S_{i} ; \quad f_{2 i}=\sin \varphi_{i} ; \quad f_{3 i}=\cos \varphi_{i} ; \quad f_{4 i}=S_{i} ; \\
& f_{1 i}=S_{i} \sin \varphi_{i} ; \quad f_{5 i}=S_{i} \cos \varphi_{i} ; \quad F_{i}=S_{i}^{2} \\
& P_{0}=a^{2}+e^{2}+r^{2}-l^{2} ; \quad P_{1}=-2 a ; \quad P_{2}=2 r e \cdot \sin \varphi_{0}-2 r a \cdot \cos \varphi_{0} ; \\
& P_{3}=-2 r e \cdot \cos \varphi_{0}-2 r a \cdot \sin \varphi_{0} ; \quad P_{4}=2 r \cdot \cos \varphi_{0} ; \quad P_{5}=2 r \cdot \sin \varphi_{0} ; \quad F_{i}=S_{i}^{2}
\end{aligned}
$$

Thus, the 5 required parameters of the lever mechanism of the crank press $r, a, l, e, \varphi_{0}$ are determined using 6 parameters $P_{0}, \ldots, P_{5}$. For the compatibility condition of the $P_{2}$ and $P_{3}$

$$
P_{2}=P_{5} e+\frac{P_{1} P_{4}}{2}, \quad P_{3}=-P_{4} e+\frac{P_{1} P_{5}}{2},
$$

From here the value of the eccentricity can be found $e$

$$
e=\frac{P_{2}}{P_{5}}-\frac{P_{1} P_{4}}{2 P_{5}} \text { or } e=-\frac{P_{3}}{P_{4}}+\frac{P_{1} P_{5}}{2 P_{4}}
$$

and the equation written down

$$
P_{1}\left(P_{4}^{2}+P_{5}^{2}\right)=2\left(P_{2} P_{4}+P_{3} P_{5}\right)
$$

The rest of the required parameters can be found from the ratios (27)

$$
a=-\frac{1}{2} P_{1} ; \quad r=\frac{1}{2} \sqrt{P_{4}^{2}+P_{5}^{2}} ; \quad \operatorname{tg} \varphi_{0}=\frac{P_{4}}{P_{5}} ; \quad l=\sqrt{a^{2}+e^{2}+r^{2}-P_{0}}
$$

To determine $P_{0}, P_{2}, P_{3}, P_{4}, P_{5}$, we apply the method of quadratic approximation [4], which consists in determining the minimum sum of square deviations for the positions of the mechanism $N$ taking into account (26), i.e.

$$
C=\Delta_{I}^{2} \underset{\min }{\Longrightarrow} 0 \text {. }
$$


The necessary conditions for the minimum (32) can be obtained by differentiating $C$ by $P_{j}$

$$
\frac{\partial C}{\partial P_{j}}=2 \sum_{i=1}^{N} \Delta_{i} \frac{\partial \Delta_{i}}{\partial P_{j}}=0, \quad j=0, \ldots, 5
$$

Substitute in the equations (33) $\Delta_{i}$ and its derivatives $\frac{\partial \Delta_{i}}{\partial P_{j}}$, which are calculated according to (26). As a result we get a system of linear equations with respect to the desired parameters $P_{0}, P_{2}, P_{3}, P_{4}, P_{5}$

$$
\left\{\begin{array}{l}
P_{0} \sum f_{0 i}^{2}+P_{1} \sum f_{1 i} f_{0 i}+P_{2} \sum f_{2 i} f_{0 i}+P_{3} \sum f_{3 i} f_{0 i}+P_{4} \sum f_{4 i} f_{0 i}+P_{5} \sum f_{5 i} f_{0 i}=\sum F_{i} f_{0 i} \\
P_{0} \sum f_{01} f_{1 i}+P_{1} \sum f_{1 i}^{2}+P_{2} \sum f_{2 i} f_{1 i}+P_{3} \sum f_{3 i} f_{1 i}+P_{4} \sum f_{4 i} f_{1 i}+P_{5} \sum f_{5 i} f_{1 i}=\sum F_{i} f_{1 i} \\
P_{0} \sum f_{01} f_{2 i}+P_{1} \sum f_{1 i} f_{2 i}+P_{2} \sum f_{2 i}{ }^{2}+P_{3} \sum f_{3 i} f_{2 i}+P_{4} \sum f_{4 i} f_{2 i}+P_{5} \sum f_{5 i} f_{2 i}=\sum F_{i} f_{2 i} \\
P_{0} \sum f_{01} f_{3 i}+P_{1} \sum f_{1 i} f_{3 i}+P_{2} \sum f_{2 i} f_{3 i}+P_{3} \sum f_{3 i}{ }^{2}+P_{4} \sum f_{4 i} f_{3 i}+P_{5} \sum f_{5 i} f_{3 i}=\sum F_{i} f_{3 i} \\
P_{0} \sum f_{01} f_{4 i}+P_{1} \sum f_{1 i} f_{4 i}+P_{2} \sum f_{2 i} f_{4 i}+P_{3} \sum f_{3 i} f_{4 i}+P_{4} \sum f_{4 i}+P_{5} \sum f_{5 i} f_{4 i}=\sum F_{i} f_{4 i} \\
P_{0} \sum f_{01} f_{5 i}+P_{1} \sum f_{1 i} f_{5 i}+P_{2} \sum f_{2 i} f_{5 i}+P_{3} \sum f_{3 i} f_{5 i}+P_{4} \sum f_{4 i} f_{5 i}+P_{5} \sum f_{5 i}^{2}=\sum F_{i} f_{5 i}
\end{array}\right.
$$

The system (34) must meet the minimum condition (32). Let's find from the first 5 equations of the system (34) coefficients $P_{i}(\mathrm{i}=0,2,3,4,5)$ expressed in $P_{1}$

$$
P_{i}=c_{i}+d_{i} P_{1}, \quad i=0,2, \ldots, 5
$$

Substitute (31) in the coupling equations (28) with (22), then we get one equation with respect to $P_{1}$

$$
P_{1}\left[\left(c_{4}+d_{4} P_{1}\right)^{2}+\left(c_{5}+d_{5} P_{1}\right)^{2}\right]=2\left[\left(c_{2}+d_{2} P_{1}\right)\left(c_{4}+d_{4} P_{1}\right)+\left(c_{3}+d_{3} P_{1}\right)\left(c_{5}+d_{5} P_{1}\right)\right],
$$

which is converted to a third-degree equation

$$
\begin{aligned}
& P_{1}^{3}\left(d_{4}^{2}+d_{5}^{2}\right)+P_{1}^{2}\left(2 c_{4} d_{4}+2 c_{5} d_{5}-2 d_{2} d_{4}-2 d_{3} d_{5}\right)+ \\
& +P_{1}\left(c_{4}^{2}+c_{5}^{2}-2 c_{2} d_{4}-2 d_{2} c_{4}-2 c_{3} d_{5}\right)=2\left(c_{2} c_{4}+c_{3} c_{5}\right)
\end{aligned}
$$

Solving this cubic equation, we find $P_{1}$, and then using the formula (35) we find $P_{0}, P_{2}, P_{3}, P_{4}, P_{5}$ coefficients. Then, based on the formulas (27), the desired parameters of $r, a, l, e, \varphi_{0}$ mechanism that implements the law (2) or (20) are determined. Thus, the problem of synthesis of this crank press mechanism by the quadratic approximation method is fundamentally solved.

\subsection{Kinematic synthesis of the workpiece feed mechanism}

The feed-and-remove mechanism works as follows (Figure 3): the slider 5 occupies three positions sequentially: 1 - upper; 2 - middle; 3 - lower position, when the workpiece is stamped, respectively, the slider 9 occupies three positions: 1 - right position where the workpiece is siezed to the feed table; 2 - average position, feed the workpiece into the matrix (table) and remove the finished stamping; 3 - left position, removal of the finished workpiece. 
Kinematic synthesis of the rocker-slider mechanism $I(7) \Rightarrow I I(8,9)$ is performed using three specified positions of the slider and rocker [24]. The method is described in an analytical way.

So, $x_{\mathrm{O}_{2}}$ and $y_{\mathrm{O}_{2}}$ coordinates are known, the equation of the forward stroke of the slider relative to $O x y$ system has the form $y=-y_{O_{2}}-h_{9}$. On this line, $B_{1}\left(x_{1}, y_{1}\right), B_{2}\left(x_{2}, y_{2}\right)$, $B_{3}\left(x_{3}, y_{3}\right)$ three slider positions are set, and $y_{I}=-y_{O_{2}}-h_{9}, I=1,2,3$ are considered to be set $\varphi_{71}^{(1,2,3)}=\tan ^{-1}\left(\frac{y_{K}-y_{O_{2}}}{x_{K}-x_{O_{2}}}\right)_{(1,2,3)}$ that correspond to the three positions of the slider 5 (see Figure 3). The algorithm for the synthesis of the rocker-slider mechanism is as follows:

1. Calculate the distance between $O_{2}\left(x_{O_{2}}, y_{O_{2}}\right)$ point and the corresponding $B_{1}\left(x_{1}, y_{1}\right)$, $B_{2}\left(x_{2}, y_{2}\right), B_{3}\left(x_{3}, y_{3}\right)$ points using the formulas

$$
\sqrt{\left(x_{I}-x_{O_{2}}\right)^{2}+\left(y_{I}-y_{O_{2}}\right)^{2}}=l_{i}, \quad i=1,2,3 .
$$

2. Calculate $\varphi_{71}^{(2)}-\varphi_{71}^{(1)}$ and $\varphi_{71}^{(3)}-\varphi_{71}^{(1)}$ angle difference using the formula $\varphi_{71}^{(1,2,3)}=$ $\tan ^{-1}\left(\frac{y_{K}-y_{O_{2}}}{x_{K}-x_{O_{2}}}\right)_{1,2,3}$.

3. On a circle with a radius $l_{2}$ based on the equation $\left(x-x_{O_{2}}\right)^{2}+\left(y-y_{O_{2}}\right)^{2}=l_{2}^{2}$, find the coordinates $B_{2}^{\prime}\left(x_{2}^{\prime}, y_{2}^{\prime}\right)$ : find $d_{2}=2 l_{2} \sin \frac{\varphi_{71}^{(2)}-\varphi_{71}^{(1)}}{2}$, then

$$
x_{2}^{\prime}=x_{2}-d_{2} \cos \frac{\pi-\varphi_{71}^{(2)}+\varphi_{71}^{(1)}}{2}, \quad y_{2}^{\prime}=y_{2}+d_{2} \sin \frac{\pi-\varphi_{71}^{(2)}+\varphi_{71}^{(1)}}{2}
$$

4. On a circle with a radius $l_{3}$ based on the equation $\left(x-x_{\mathrm{O}_{2}}\right)^{2}+\left(y-y_{\mathrm{O}_{2}}\right)^{2}=l_{3}^{2}$, find the coordinates $B_{3}^{\prime}\left(x_{3}^{\prime}, y_{3}^{\prime}\right)$ : find $d_{3}=2 l_{3} \sin \frac{\varphi_{71}^{(3)}-\varphi_{71}^{(1)}}{2}$, then

$$
x_{3}^{\prime}=x_{3}-d_{3} \cos \frac{\pi-\varphi_{71}^{(3)}+\varphi_{71}^{(1)}}{2}, \quad y_{3}^{\prime}=y_{3}+d_{3} \sin \frac{\pi-\varphi_{71}^{(3)}+\varphi_{71}^{(1)}}{2}
$$

5. Let us write equations of lines that pass through points $B_{1}\left(x_{1}, y_{1}\right)$ and $B_{2}^{\prime}\left(x_{2}^{\prime}, y_{2}^{\prime}\right)$ and $B_{2}^{\prime}\left(x_{2}^{\prime}, y_{2}^{\prime}\right)$ and $B_{3}^{\prime}\left(x_{3}^{\prime}, y_{3}^{\prime}\right): y=k_{2} x+q_{2}$ and $y=k_{3} x+q_{3}$, respectively, where $k_{2}=\frac{y_{2}^{\prime}-y_{1}}{x_{2}^{\prime}-x_{1}}$, $q_{2}=y_{1}-k_{2} x_{1}$ and $k_{3}=\frac{y_{3}^{\prime}-y_{2}^{\prime}}{x_{3}^{\prime}-x_{2}^{\prime}}, q_{2}=y_{1}-k_{3} x_{1}$.

6. Let us create equations of perpendicular lines to lines that pass through points $B_{1}\left(x_{1}, y_{1}\right)$ and $B_{2}^{\prime}\left(x_{2}^{\prime}, y_{2}^{\prime}\right)$, as well as $B_{2}^{\prime}\left(x_{2}^{\prime}, y_{2}^{\prime}\right)$ and $B_{3}^{\prime}\left(x_{3}^{\prime}, y_{3}^{\prime}\right)$ :

From the beginning we find the coordinates of $C_{2}, C_{3}$ points in the middle of the segments $\left(B_{1}\left(x_{1}, y_{1}\right), B_{2}^{\prime}\left(x_{2}^{\prime}, y_{2}^{\prime}\right)\right)$ and $\left(B_{2}^{\prime}\left(x_{2}^{\prime}, y_{2}^{\prime}\right), B_{3}^{\prime}\left(x_{3}^{\prime}, y_{3}^{\prime}\right)\right): x_{C_{2}}=\frac{x_{2}^{\prime}+x_{1}}{2}, y_{C_{2}}=$ $\frac{y_{2}^{\prime}+y_{1}}{2}$, and then the equations $x_{C_{3}}=\frac{x_{2}^{\prime}+x_{3}^{\prime}}{2}, y_{C_{3}}=\frac{y_{2}^{\prime}+y_{3}^{\prime}}{2}$, of perpendicular lines have the form

$y=-\frac{1}{k_{2}} x+q_{4}$ and $y=-\frac{1}{k_{3}} x+q_{5}$, where $q_{4}=y_{C_{2}}+\frac{1}{k_{2}} x_{C_{2}}, q_{5}=y_{C_{3}}+\frac{1}{k_{3}} x_{C_{3}}$. 
7. Next, we solve the equations of two lines $y=-\frac{1}{k_{2}} x+q_{4}$ and $y=-\frac{1}{k_{3}} x+q_{5}$, relative to $P\left(x_{P}, y_{P}\right)$ center coordinate:

$$
x_{P}=\frac{k_{2} k_{3}}{k_{2}-k_{3}}\left(q_{5}-q_{4}\right), \quad y_{P}=-\frac{1}{k_{3}} x_{P}+q_{5},
$$

8. As a result, we find the length of the rocker $l_{7}$ and the connecting rod $l_{9}$ using the formulas

$$
l_{7}=\sqrt{\left(x_{P}-x_{O_{2}}\right)^{2}+\left(y_{P}-y_{O_{2}}\right)^{2}}, \quad l_{9}=\sqrt{\left(x_{P}-x_{B_{1}}\right)^{2}+\left(y_{P}-y_{B_{1}}\right)^{2}},
$$

also the constant length of the base joint 7

$$
l_{K R}=\sqrt{\left(x_{P}-x_{K}\right)^{2}+\left(y_{P}-y_{K}\right)^{2}} .
$$

\subsection{Results and discussions}

In order to solve the problem of analysis and synthesis of the six-lever mechanism (Figure 1), a program was developed in the integrated Maple environment.

To assess the quality of the sintered crank press stamping mechanism, the following criteria are used $K_{1}, K_{2}$

$$
K_{1}=T_{\max }^{\prime \prime}+\xi_{1}\left|T_{\min }^{\prime \prime}\right|, \quad K_{2}=\left(T^{\prime} T^{\prime \prime}\right)_{\max }+\xi_{2}\left|\left(T^{\prime} T^{\prime \prime}\right)_{\min }\right|
$$

It is known [4] that geometric characteristics significantly affect the dynamics of mechanisms. Therefore, the criteria (38) can be used as preliminary dynamic criteria [4], which are used to compare different laws of motion, as well as to synthesize new laws that have optimal properties in a certain sense. This problem is relevant when studying the dynamics of the crank press and its further automation. Criterion (38) allows monitoring the pulsation of inertial loads on the slider and flywheel, from the external load on the workpiece side in the crank press [6].

Example. Consider an example of the synthesis of the Stephenson lever mechanism of a crank press. Initial data for synthesis: law of motion of slider $5: S=S(\varphi)$, (see Figure 2) on the section of the crank rotation angle $0 \leq \varphi \leq 2 \pi$. Slider stroke $S_{\max }=120 \mathrm{~mm}$. The angular velocity of the crank is constant $\omega=\dot{\varphi}=10 \mathrm{rad} / \mathrm{s}$.

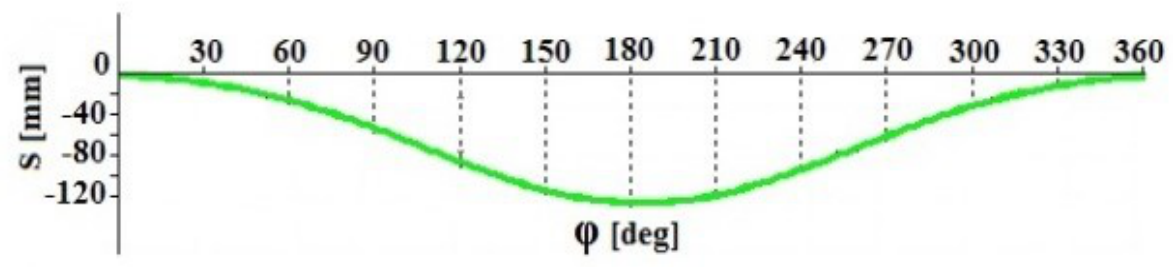

Figure 2: The law of motion of the slider of a six-lever mechanism

Note that since the slider moves in the opposite direction of the axis $O y$, the axis $O x$ is directed to the right, then as a result of modeling the graphs relative to the specified graph in Figure 2 will be shifted to the left by $-\pi / 2$. 
As a result of synthesis based on the above method in the Maple integrated environment, the following parameters of the Stephenson mechanism are obtained:

$$
r=60 \mathrm{~mm}, l=160 \mathrm{~mm}, a=41,85 \mathrm{~mm}, b=43 \mathrm{~mm}, e=0, \varphi_{0}=-\pi / 2 .
$$

According to the algorithms for the synthesis of the rocker-slider mechanism described in this paper, the mechanism with the following data is synthesized: $l_{8}=134.5 \mathrm{~mm}, l_{7}=86 \mathrm{~mm}$. Other geometric parameters of the stamping mechanism are summarized in Table 1.

\begin{tabular}{|l|l|l|l|l|l|l|l|}
\hline$B^{\prime} D$ & $C^{\prime} D$ & $l_{6}$ & $\begin{array}{l}l_{71} \\
O_{2} K\end{array}$ & $K R$ & $h_{9}$ & $x_{O_{2}}$ & $y_{O_{2}}$ \\
\hline $163 \mathrm{~mm}$ & $36 \mathrm{~mm}$ & $134.5 \mathrm{~mm}$ & $103.5 \mathrm{~mm}$ & $176.6 \mathrm{~mm}$ & $56.5 \mathrm{~mm}$ & $136,5 \mathrm{~mm}$ & $-207.2 \mathrm{~mm}$ \\
\hline
\end{tabular}

The kinematic analysis of the mechanism in the ASIAN-2014 environment is carried out [25]. Figure 3 shows a kinematic diagram of the Stephenson synth mechanism with an analysis of the trajectory of the characteristic hinges.

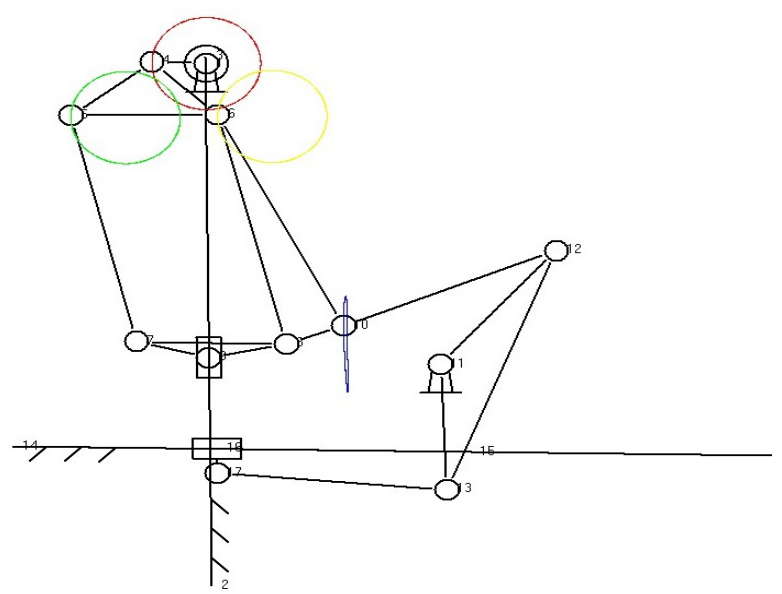

Figure 3: Kinematic analysis of the stamping mechanism

Figures 4, 5, 6 show graphs of movement, speed, and acceleration of work joints: of the slider 5 and slider 9. Analysis of slider 5 movement graph (Figure 4,a) shows that the mechanism implements the specified law of movement of the working body (Figure 2). Slider 5 takes the upper position at $\varphi=\pi / 2$, the lower position at $\varphi=3 \pi / 2$. The forward and reverse moves of the slider occur at $\varphi \in\left(\frac{\pi}{2}, \frac{3 \pi}{2}\right)$ and $\varphi \in\left(\frac{3 \pi}{2}, \frac{\pi}{2}\right)$. In the working lower position, slider 5 makes a uniform movement in the $\varphi \in\left(246^{\circ}, 282^{\circ}\right)$ interval.

The amplitude of the slider speed change at $\varphi^{(2)}=186^{\circ}$ and $\varphi^{(4)}=339^{\circ}$ remains the same (Figure 5, a). The amplitude of the change in the slider acceleration at $\varphi^{(1)}=87^{\circ}$ and $\varphi^{(3)}=264^{\circ}$ is 1.5 (Figure 6 , a). At the interval $\varphi \in\left(53^{\circ}, 124^{\circ}\right)$, the acceleration of slider 5 is close to constant and the speed is linear.

Slider 9 makes a uniform movement in the interval $\varphi \in\left(66^{\circ}, 180^{\circ}\right)$. Acceleration is close to zero, speed is constant. The amplitude of forward slider movement is greater than the reverse by 4.7 times; speed -2 times, acceleration -1.5 times (Figures 4 ,b, 5,b, 6,b). There are no abrupt changes in kinematic parameters that cause shock loads. 


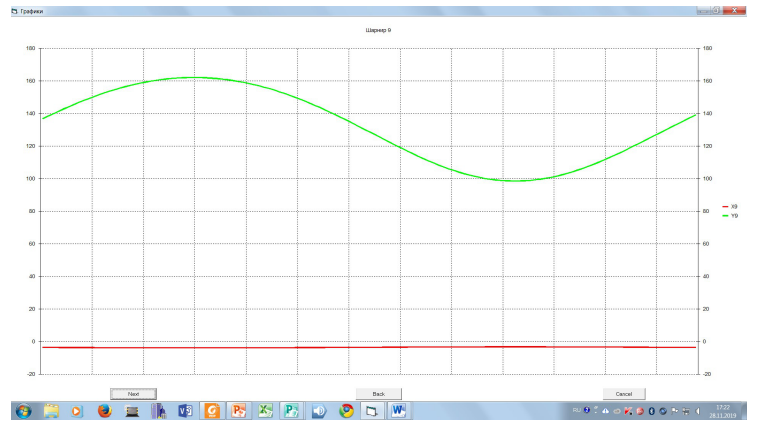

a)

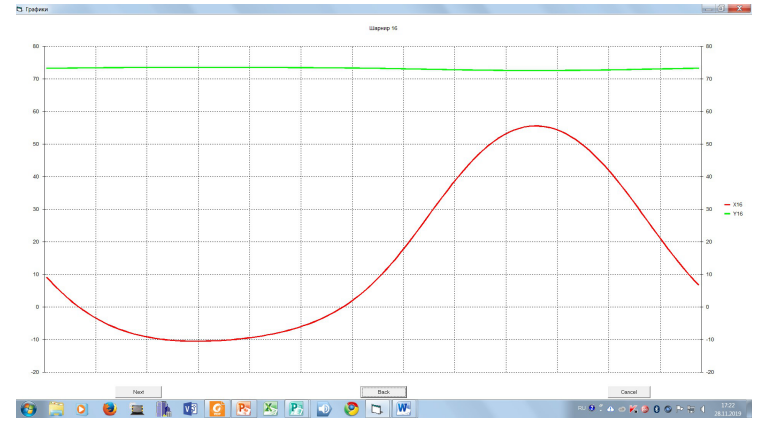

b)

Figure 4: Analysis of the provisions of the stamping mechanism

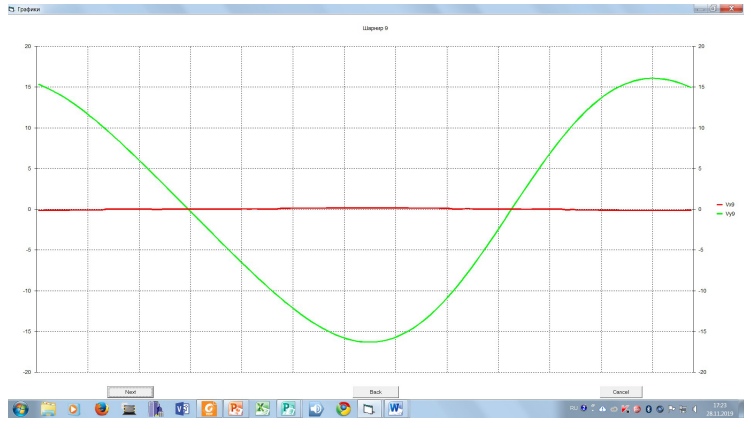

a)

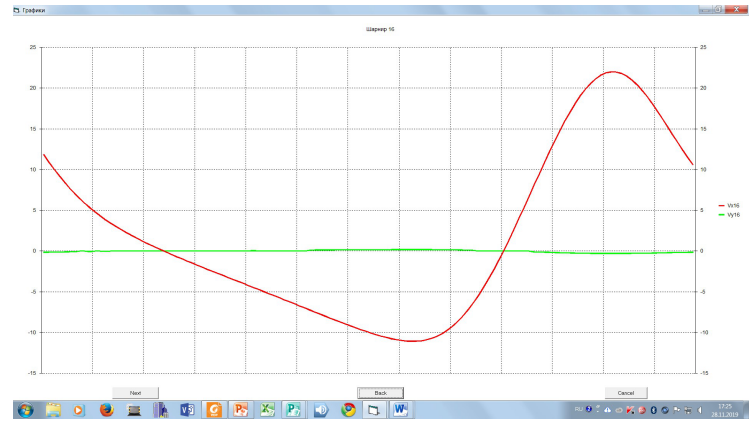

b)

Figure 5: Analysis of the stamping mechanism speeds

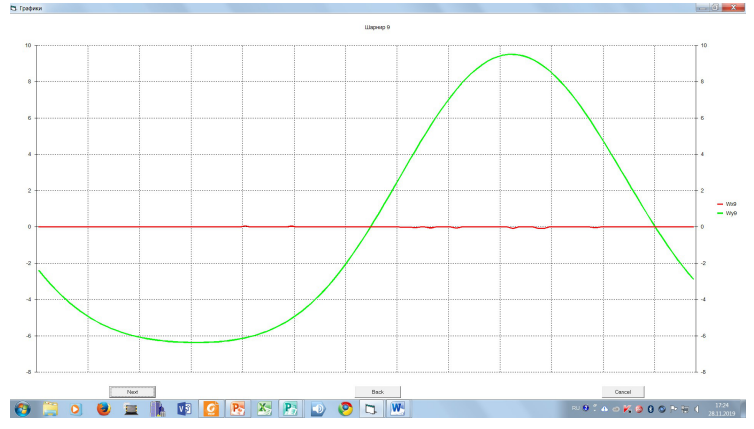

a)

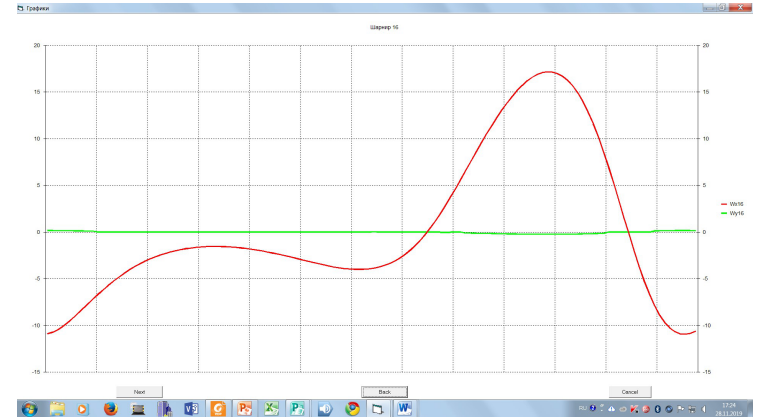

b)

Figure 6: Analysis of the stamping mechanism acceleration

\section{Conclusions}

A method for kinematic synthesis of link mechanisms based on the mean-square minimization of the objective function has been developed, and a method for deriving this objective function is proposed taking into account the structural (constructive) features of the mechanism. Based on this method and the synthesis method for the three given positions of the slider and rocker of the four-link crank-slide mechanism, algorithms were constructed and Stephenson's stamping mechanism is synthesized with additional workpiece feeding mecha- 
nism. Numerical modeling programs based on the Maple environment were developed, and verification calculations were performed to analyze the position, velocities, and accelerations in the ASIAN-2014 environment.

\section{References}

[1] Bocharov Yu.A., Kuznechno-shtampovochnoe oborudovanie [Forging and stamping equipment] (M.: Academy, 2008$): 480$.

[2] Tuleshov A., Jomartov A., "Vector method for kinetostatic analysis of planar linkages", Journal of the Brazilian Society of Mechanical Sciences and Engineering Vol. 40 (2018): 55-69.

[3] Tuleshov A., Jomartov A., Kaimov A., Modeling dynamics of planetary gear of crank press on SimulationX" , Proceedings of Second International Conference of IFToMM Italy, Cassino (2018).

[4] Tuleshov A.K., Dzhomartov A.A., Kuatova M.Z., "Model dvizheniya krivoshipnogo pressa na baze ryichazhnogo mehanizma 4-go klassa [The model of the movement of the crank press on the basis of the lever mechanism of the 4th class]" , Annotations of reports of the 7th All-Russian Congress on fundamental problems of theoretical and applied mechanics Russian Federation, Ufa. 19-24 of August (2019): 56.

[5] Tuleshov A., Jomartov A., Kuatova M., "Simulation of the crank press dynamics by SimulationX software", Journal of Mathematics, Mechanics and Computer Science No 2 (102) (2019): 22-33.

[6] Erkan Kütük M., Canon Dülger L., "Gibridnaya press-sistema: voprosyi proektirovaniya dvizheniya i obratnoy kinematiki [Hybrid press system: the design of motion and inverse kinematics]", Engineering Science and Technology, an International Journal Volume 19, Issue 2 (2016): 846-856.

[7] Tokuz L.C., "Hybrid machine modelling and control (Ph.D. thesis)", Liverpool Polytechnic (1992).

[8] Dülger L.C., Kireçci A., "Hibrid Manipülatörün Modellenmesi ve Simülasyonu", Ulusal Makine Teorisi Sempozyumu YTU, Istanbul (1995): 311-320.

[9] Dülger L.C., Kireçci A., "A study on a hybrid actuator", Mech. Mach. Theory 35 (1999): 1141-1149.

[10] Yuan Z., Gilmartin M.J., Douglas S.S., "Design of hybrid machines for nonuniform motion production" , Proc. Inst. Mech. Eng. 219 (2005): 491-499.

[11] Ouyang P.R., Li Q., Zhang W.J., "Design, modelling and control of a hybrid machine system", Mechatronics 14 (2004): 1197-1217.

[12] Zhang K., "Optimization dynamics design of hybrid driving mechanisms", Proceedings of the 2006 IEEE International Conference on Mechatronics and Automation Luoyang, Henan, China (2006): 1914-1919.

[13] Connor A.M., Douglas S.S., Gilmartin M.J., "The synthesis of hybrid five bar path generating mechanisms using genetic algorithms", Genetic Algorithms in Engineering Systems: Innovations and Applications, IET, Sheffield No 414 (1995): 313-316.

[14] Dülger L.C., Kireçci A., Topalbekiroglu M., "Modeling and simulation of a hybrid actuator" , Mech. Mach. Theory 38 (2003): 395-407.

[15] Yu H., "Modelling and control of hybrid machine systems, a five-bar mechanism case", Int. J. Autom. Comput. 3 (2006): 235-243.

[16] Li H., Zhang Y., "Seven bar mechanical press with hybrid driven mechanism for deep drawing; part 1: kinematics analysis and optimum design, part 2: dynamic modeling and simulation", J. Mech. Sci. Technol. 24 (11) (2010): 2153-2160, 2161-2167.

[17] Li C.H., Tso P.L., "Experimental study on a hybrid driven press using iterative learning control", Int. J. Mach. Tools Manuf. 48 (2008): 209-219.

[18] Tso P.L., Li C.H., "Study of servo press with a flywheel", J. Adv. Mech. Des. Syst. Manuf. 2 (1) (2008): 1-11.

[19] Tso P.L., "Optimal design of a hybrid-driven servo press and experimental verification", J. Mech. Des. 132 (3) (2010): 4. 
[20] Vulfson I.I., Kolovskiy M.Z., Peisakh E.Y., et al. "Mehanika mashin: uchebnoe posobie dlya vtuzov. Pod redaktsiey prof. G.A. Smirnova [Mechanics of machines: a manual for technical schools. Edited by prof. G.A. Smirnova]" , Moscow: Vysshaya Shkola Publishing House (1996): 511.

[21] Yevgrafov M.Z., Semyonov Y.A., Slousch A.V., "Teoriya mehanizmov i mashin: uchebnoe posobie [Theory of mechanisms and machines: a training manual]", Moscow: Academia Publishing Center (2006): 560.

[22] Chval Z.M., Cechura M., "Optimization of Power Transmission on Mechanical Forging Press", Procedia Engineering (2014): 890-896.

[23] Drakunov A.Y., Drakunov Y.M., "Interpolyatsionnyiy sintez mehanizma v sisteme Maple [Interpolation synthesis of a mechanism in the Maple system]", Proceedings of the 7th International Conference "Problems of the Mechanics of Modern Machines" Russia, Ulan-Ude (2018): 29-33.

[24] Baranov G.G., Theory of mechanisms and machines (Moscow : Mashinostroyeniye, 1967): 508.

[25] Dzhamalov N.K., "For "ATLAS, a complex of programs for the automated design of lever hoisting mechanisms" , Inclusion in the state register of Computer Programs (CAD) NBo 5103 (2019). 